\title{
Nutritional Status among Rural Community Elderly in the Risk Area of Liver Fluke, Surin Province, Thailand
}

\author{
Soraya J Kaewpitoon ${ }^{1,2,3, *}$, Niwatchai Namwichaisirikul ${ }^{1}$, Ryan A Loyd ${ }^{1}$, Seekaow \\ Churproong ${ }^{1}$, Naporn Ueng-Arporn ${ }^{4}$, Likit Matrakool $^{5}$, Taweesak Tongtawee ${ }^{5}$, \\ Ratana Rujirakul ${ }^{2}$, Porntip Nimkhuntod ${ }^{6}$, Parichart Wakhuwathapong ${ }^{2}$, \\ Natthawut Kaewpitoon ${ }^{2,3,7}$
}

\begin{abstract}
Thailand is becoming an aging society, this presenting as a serious problem situation especially regarding health. Chronic diseases found frequently in the elderly may be related to dietary intake and life style. Surin province has been reported as a risk area for liver fluke with a high incidence of cholangiocarcinma especially in the elderly. Therefore, this study aimed to determine the nutritional status and associated factors among elderly in Surin province, northeast of Thailand. A community-based cross-sectional study was conducted among 405 people aged 60 years and above, between September 2012 and July 2014. The participants were selected through a randomized systematic sampling method and completed a pre-designed questionnaire with general information, food recorded, weight, height, waist circumference, and behavior regarding to food consume related to liver fluke infection. The data were analyzed using descriptive statistics and Spearman's rank correlation coefficients. The majority of participants was female $(63.5 \%)$, age between $60-70$ years old $(75.6 \%)$, with elementary school education (96.6\%), living with their (78.9\%), and having underlying diseases $(38.3 \%)$. Carbohydrate (95.3\%)

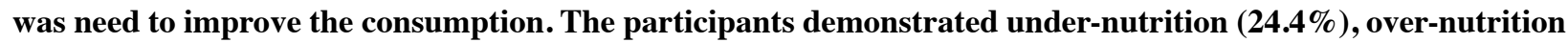
$(\mathbf{1 6 . 4 \% )}$, and obesity $(\mathbf{1 5 . 4 \% )}$. Elderly had a waist circumference as the higher than normal level $(34.0 \%)$. Gender, female, age 71-80 years old, elementary school and underlying diseases were significantly associated with poor nutritional status. The majority of them had a high knowledge (43.0\%), moderate attitude (44.4\%), and moderate practice $\mathbf{( 4 6 . 2 \%}$ ) regarding food consumption related to liver fluke infection. In conclusion, these findings data indicated that elderly age group often have an under- or over-nutritional status. Carbohydrate consumption needs to be improved. Some elderly show behavior regarding food consumption that is related to liver fluke infection hat needs to be improved, so that health education pertaining good nutrition is required.
\end{abstract}

Keywords: Nutritional status - elderly - liver fluke - Surin province - Thailand

Asian Pac J Cancer Prev, 16 (18), 8391-8396

\section{Introduction}

Thailand is increasing the number older age and becoming the elderly society in which many problems has been reported. Thailand has been reported that the $65,400,000$ populations in 2012 (National Statistical Office, Ministry of Information and Communication Technology, Thailand, 2012). Meanwhile, Thai elderly was prospected regarding the increasing number by the United Nation between 1990 to 2040 and found that the increasing number of populations were $185.1 \%, 326 \%$, $526.3 \%, 696.6 \%$, and $769.8 \%$ in $1990,2000,2010,2020$, and 2040 (Nation United, 1999). Health problems in elderly are mostly related to their previous nutrition status such as malnutrition, cholesterol, hypertension, diabetes, obesity, myocardial infarction, gout, obesity, anemia, diabetes, and cancer (Mioche et al., 2004; Lennie et al., 2006; Mahon et al., 2007; Esser et al., 2014; McCartney et al., 2015).

Since then Surin province of Thailand, has been reported that are the epidemic areas of liver fluke and the high incident of cholangiocarcinoma; bile duct cancer that related to liver fluke infection (Kaewpitoon et al., 2008a; Kaewpitoon et al., 2008b; Sripa and Pairojkul, 2008; Sithithaworn et al., 2012). We previously reported that the Opisthorchis viverrini infection in elderly was found $9.91 \%$, and followed by Strongyloides stercoralis (4.80\%) and hookworm $(1.50 \%)$, respectively (Kaewpitoon et al., 2012). In addition, O. viverrini infection was a cross-sectional survey in the rural communities of Surin 
province, during September 2013 to July 2014, and found that $O$. viverrini infection was $6.47 \%$, the high frequently was found in the age group 61-70 (19.40\%) and 71-80 year old (19.35\%), respectively (Kaewpitoon et al., unpublished). Nutrition status and behavior are need required to concerned, especially in the risk areas of liver fluke infection. Therefore, this study aims to determine the nutritional status, behavior, and associated factors among elderly in Surin province, northeast of Thailand. These findings data may able useful for further planning of the health education campaign pertaining good nutrition in the risk group.

\section{Materials and Methods}

A community-based cross-sectional study was conducted among 405 elders aged 60 years old and above, between September 2012 and July 2014 in Surin province where is located in the northeastern region of Thailand. A total area about 8,124 kilometer2, approximately 450 kilometers away from Bangkok city (the capital of Thailand) by cars and 420 kilometers by train. The province is subdivided into 17 districts; Mueang Surin, Chumphon Buri, Tha Tum, Chom Phra, Prasat, Kap Choeng, Rattanaburi, Sanom, Sikhoraphum, Sangkha, Lamduan, Samrong Thap, Buachet, Phanom Dong Rak, Si Narong, Khwao Sinarin, and Non Narai district. All participants were randomized selected through systematic sampling method. Necessary permission from the concerned authorities was taken and a survey was conducted using pre-designed questionnaires. Prior informed consent was taken. For those not available in the first interview another visit was made to minimize nonresponse. All of participants was completed the predesigned questionnaire with the general information, food recorded, and knowledge, attitude, and practice regarding to food consume related to liver fluke infection. Reliability and validity of questionnaire was analyzed, knowledge (Kruder-Richardon-20) $=0.89$, attitude and practice (coefficient of Cronbach's alpha) $=0.80$ and 0.78 , respectively. Weight and height were computed and assessed for body mass index (BMI) following World Health Organization (WHO) reassesses appropriate bodymass index for Asia Population (Choo 2002). Briefly, BMI was classified to under-nutrition; $<18.50 \mathrm{~kg} / \mathrm{m}^{2}$, normal; $18.50-24.99 \mathrm{~kg} / \mathrm{m}^{2}$, over-nutrition; $>24.99 \mathrm{~kg} / \mathrm{m}^{2}$, and obesity; $>29 \mathrm{~kg} / \mathrm{m}^{2}$. Waist circumference was computed and assessed by using the interpretation of anthropometry following WHO assessment (1995). Waist circumference was classified to normal and higher than normal level, (male; normal level $\leq 94$ higher than normal level $>94$ $\mathrm{cm}$, female; normal level $\leq 80$ higher than normal level > $80 \mathrm{~cm}$ ). Evaluation of knowledge, attitude, and practice level regarding to food consume related to liver fluke infection, was calculated and analyzed according to Bloom et al. (1971), answer correct=1, incorrect $=0$, and interpreted to high level; 19-21 point, fair level; 13-18 point, 0-12; low level. Evaluation of attitude and practice level were calculated and analyzed according to Best et al (1997), attitude with 3 choices (agree, moderate, disagree): positive question $=3,2,1$, negative question $=1,2,3$ and interpreted to good level; $2.67-3.00$ point, moderate level; 1.33-2.66 point, 1.00-1.32 point; poor level. Practice with 3 choices (regular, irregular, and never): positive question $=3,2,1$, negative question $=1,2,3$ and interpreted to good level; 2.67-3.00 point, moderate level; 1.33-2.66 point, 1.00-1.32 point; poor level. Descriptive statistical and Spearman's rank correlation coefficients were analyzed with SPSS software. The protocol was approved by the ethical review committee of Suranaree University of Technology, 2012.

\section{Results}

The majority of participants was female $(63.46 \%)$, age between $60-70$ years old $(75.56 \%)$, elementary school (96.6\%), lives with thire child $(78.86 \%)$, and had an

Table 1. Baseline characteristics of elderly in Surin province, Thailand

\begin{tabular}{lcc}
\hline Characteristics & Number $(\mathrm{n}=405)$ & $\%$ \\
\hline Gender & & \\
$\quad$ Female & 257 & 63.46 \\
$\quad$ Male & 148 & 36.54 \\
Age & & \\
$\quad 60-70$ years old & 306 & 75.56 \\
$\quad 71-80$ years old & 81 & 20 \\
$\quad$ 80-90 years old & 2 & 0.49 \\
$\quad$ Not identified & 16 & 3.95 \\
Education & & \\
$\quad$ Elementary school & 375 & 96.6 \\
$\quad$ Junior high school & 14 & 2.09 \\
$\quad$ Senior High school & 9 & 0.79 \\
$\quad$ Undergraduate & 7 & 0.52 \\
Caregiver & & \\
$\quad$ Child & 303 & 78.86 \\
$\quad$ Relative & 32 & 5.42 \\
$\quad$ Others & 70 & 15.72 \\
Underlying disease & & \\
$\quad$ Yes & 155 & 38.27 \\
$\quad$ No & 250 & 61.73 \\
\hline
\end{tabular}

Table 2. Food Consumption of Ederly in Surin Province, Thailand, by Food Group

\begin{tabular}{|c|c|c|c|c|c|c|}
\hline \multirow[t]{2}{*}{ Food group } & \multicolumn{2}{|c|}{ Need to improve } & \multicolumn{2}{|c|}{ Inappropriate } & \multicolumn{2}{|c|}{ Appropriate } \\
\hline & No. & $\%$ & No. & $\%$ & No. & $\%$ \\
\hline Protein & 10 & 2.47 & 98 & 24.20 & 297 & 73.33 \\
\hline Carbohydrate & 386 & 95.31 & 11 & 2.72 & 8 & 1.98 \\
\hline Vitamin and mineral & 15 & 3.70 & 91 & 22.47 & 299 & 73.83 \\
\hline Fat & 73 & 18.02 & 163 & 40.25 & 169 & 41.73 \\
\hline
\end{tabular}


Table 3. Nutritional Status of Elderly in Surin Province, Thailand, by Waist Circumference and Body Mass Index

\begin{tabular}{lcc}
\hline Characteristics & Number $(\mathrm{n}=405)$ & $\%$ \\
\hline Waist Circumference & & \\
Normal level & 267 & 65.96 \\
Higher than normal level & 138 & 34.04 \\
Body Mass Index $(\mathrm{BMI})$ & & \\
Under-nutrition $\left(\mathrm{BMI}<18.50 \mathrm{~kg} / \mathrm{m}^{2}\right)$ & 99 & 24.43 \\
Normal $\left(\mathrm{BMI} 18.50-24.99 \mathrm{~kg} / \mathrm{m}^{2}\right)$ & 178 & 43.83 \\
Over-nutrition $\left(\mathrm{BMI}>24.99 \mathrm{~kg} / \mathrm{m}^{2}\right)$ & 66 & 16.37 \\
Obesity $\left(\mathrm{BMI}>29 \mathrm{~kg} / \mathrm{m}^{2}\right)$ & 62 & 15.37 \\
\hline
\end{tabular}

underlying disease (38.27\%) mainly diabetes melletus, cardiovascular disease, hypertension, and anemia (Table 1). Food consumption of elderly was analyzed and found that food group of vitamine and mineral (73.83\%), protein $(73.33 \%)$ were appropriated consumed, while carbohydrate consumption was need to improve in this group (Table 2). Nutritional status of elderly was calculated by waist circumference and body mass index and found that The majority of participants had a normal nurtrition level (43.83\%), followed by under-nurtition (24.43\%), and over-nutrition (16.37\%), respectively (Table 3). While, obesity was found $15.37 \%$ in this group. Elderly had a

Table 4. Factor Associated with Nutritional Status of Elderly in Surin province, Thailand, by Body Mass Index

\begin{tabular}{|c|c|c|c|c|c|c|c|c|c|c|c|c|}
\hline Characteristics & $\begin{array}{l}\text { Number } \\
(\mathrm{n}=405)\end{array}$ & $\%$ & $\begin{array}{c}\text { Normal } \\
\text { nutrition }\end{array}$ & $\%$ & $\begin{array}{c}\text { Under } \\
\text { nutrition }\end{array}$ & $\%$ & $\begin{array}{c}\text { Over } \\
\text { nutrition }\end{array}$ & $\%$ & Obesity & $\%$ & rs & $\mathrm{P}$ \\
\hline \multicolumn{13}{|l|}{ Gender } \\
\hline Female & 257 & 63.46 & 98 & 24.2 & 66 & 16.3 & 41 & 10.12 & $52 * *$ & 12.84 & 0.21 & 0.01 \\
\hline Male & 148 & 36.54 & 80 & 19.75 & 33 & 8.15 & 25 & 6.18 & 10 & 2.47 & & \\
\hline \multicolumn{13}{|l|}{ Age } \\
\hline 60-70 years old & 306 & 75.56 & 134 & 33.09 & 64 & 15.8 & 56 & 13.83 & 52 & 12.84 & & \\
\hline $71-80$ years old & 81 & 20 & 24 & 5.93 & $38 * *$ & 9.38 & 12 & 2.96 & 7 & 1.73 & 0.25 & 0.01 \\
\hline $80-90$ years old & 2 & 0.49 & 1 & 0.25 & 1 & 0.25 & & 0 & 0 & 0 & & \\
\hline Not identified & 16 & 3.95 & 15 & 3.7 & 1 & 0.25 & 0 & 0 & 0 & 0 & & \\
\hline \multicolumn{13}{|l|}{ Education } \\
\hline Elementary school & 375 & 96.6 & 164 & 40.49 & $97 *$ & 23.95 & 59 & 14.57 & 55 & 13.58 & 0.16 & 0.05 \\
\hline Junior high school & 14 & 2.09 & 8 & 1.98 & 2 & 0.49 & 2 & 0.49 & 2 & 0.49 & & \\
\hline High school & 9 & 0.79 & 7 & 1.73 & 0 & 0 & 1 & 0.25 & 1 & 0.25 & & \\
\hline Undergraduate & 7 & 0.52 & 6 & 1.48 & 1 & 0.25 & 0 & 0 & 0 & 0 & & \\
\hline \multicolumn{13}{|l|}{ Underlying disease } \\
\hline Yes & 155 & 38.27 & 75 & 18.52 & 41 & 10.12 & $27 *$ & 6.67 & $12 *$ & 2.96 & 0.11 & 0.05 \\
\hline No & 250 & 61.73 & 150 & 37.04 & 60 & 14.81 & 34 & 8.4 & 6 & 1.48 & & \\
\hline Caregiver & & & & & & & & & & & 0.11 & 0.29 \\
\hline Child & 303 & 78.86 & 143 & 35.31 & 60 & 14.81 & 52 & 12.84 & 48 & 11.85 & & \\
\hline Relative & 32 & 5.42 & 7 & 1.73 & 16 & 3.95 & 6 & 1.48 & 3 & 0.74 & & \\
\hline Others & 70 & 15.72 & 28 & 6.91 & 25 & 6.17 & 7 & 1.73 & 10 & 2.47 & & \\
\hline
\end{tabular}

Table 5. Factor Associated with Nutritional Status of Elderly in Surin Province, Thailand, by Weist Circumference

\begin{tabular}{|c|c|c|c|c|c|c|c|c|}
\hline Characteristics & $\begin{array}{l}\text { Number } \\
(n=405)\end{array}$ & $\%$ & $\begin{array}{c}\text { Normal } \\
\text { level }\end{array}$ & $\%$ & $\begin{array}{l}\text { Higher than } \\
\text { normal level }\end{array}$ & $\%$ & rs & P-value \\
\hline \multicolumn{9}{|l|}{ Gender } \\
\hline Female & 257 & 63.46 & 143 & 55.64 & $114 * *$ & 44.36 & 0.33 & 0.01 \\
\hline Male & 148 & 36.54 & 124 & 44.36 & 24 & 16.22 & & \\
\hline \multicolumn{9}{|l|}{ Age } \\
\hline 60-70 years old & 306 & 75.56 & 201 & 49.63 & $105^{*}$ & 25.93 & 0.03 & 0.05 \\
\hline $71-80$ years old & 81 & 20 & 49 & 12.1 & 32 & 7.9 & & \\
\hline $80-90$ years old & 2 & 0.49 & 1 & 0.25 & 1 & 0.25 & & \\
\hline Not identified & 16 & 3.95 & 16 & 3.94 & 0 & 0 & & \\
\hline \multicolumn{9}{|l|}{ Education } \\
\hline Elementary school & 375 & 96.6 & 246 & 60.75 & $129 *$ & 31.85 & 0.08 & 0.05 \\
\hline Junior high school & 14 & 2.09 & 9 & 2.22 & 5 & 1.23 & & \\
\hline High school & 9 & 0.79 & 6 & 1.48 & 3 & 0.74 & & \\
\hline Undergraduate & 7 & 0.52 & 6 & 1.48 & 1 & 0.25 & & \\
\hline \multicolumn{9}{|l|}{ Underlying disease } \\
\hline Yes & 155 & 38.27 & 88 & 21.73 & 67 & 16.55 & & \\
\hline No & 250 & 61.73 & 180 & 44.44 & $70 * *$ & 17.28 & 0.16 & 0.01 \\
\hline \multicolumn{9}{|l|}{ Caregiver } \\
\hline Child & 303 & 78.86 & 202 & 49.88 & 24.94 & 14.81 & 0.05 & 0.66 \\
\hline Relative & 32 & 5.42 & 22 & 5.43 & 2.47 & 3.95 & & \\
\hline Others & 70 & 15.72 & 42 & 10.37 & 29 & 6.42 & & \\
\hline
\end{tabular}


Table 6. Knowledge and Attitude of 405 Elderly, Surin Province, Thailand, Regarding to Food Consumed Related to Liver Fluke Infection

\begin{tabular}{lcl}
\hline Behaviors & $\begin{array}{c}\text { No. of participants } \\
(\mathrm{n}=405)\end{array}$ & $\%$ \\
\hline Knowledge & \\
$\quad$ High & 174 & 42.96 \\
Fair & 179 & 44.2 \\
Low & 52 & 12.84 \\
Attitude & & \\
$\quad$ Good & 158 & 39.01 \\
Moderate & 180 & 44.44 \\
Poor & 67 & 16.54 \\
Practice & & \\
$\quad$ Good & 175 & 43.21 \\
Moderate & 187 & 46.17 \\
Poor & 43 & 10.62 \\
\hline
\end{tabular}

waist circumference as a normal level $(65.96 \%)$, followed by the higher than normal level (34.04\%) (Table 3$)$. The relationship between domgraphic data and nutritional status was analyzed and found that gender, age group, edutcation, and underlying diseases were significant associated to nutritional status in which classified by body mass index. Gender, female and male were statistical significant associated to the over-nutritional status $(\mathrm{rs}=0.21$, $\mathrm{p}$-value $=0.01)$. Age groups, 71-80 years old was statistical siginificant associated to under-nutritional status ( $\mathrm{rs}=0.25$, $\mathrm{p}$-value $=0.01)$. Education, elelmentary school was statistical siginificant associated to under-nutritional status ( $r s=0.16$, $p$-value $=0.05$ ). Underlying diseases were statistical siginificant associated to over-nutritional status and obesity ( $\mathrm{rs}=0.11$, p-value $=0.05$ ). While, caregivers were not statistical siginificant associated to nutrition (Table 4). The relationship between domgraphic data and nutritional status was analyzed and found that gender, age group, edutcation, and underlying diseases were significant associated to nutrition nutritional status in which classified by weist circumference. Female ( $\mathrm{rs}=0.33$, $\mathrm{p}$-value $=0.01)$, age $60-70$ years old, $(\mathrm{rs}=0.03, \mathrm{p}$-value $=0.05)$, elelmentary school $(\mathrm{rs}=0.08$, p-value $=0.05)$, underlying diseases (rs $=0.16, \mathrm{p}$-value $=0.01)$ were statistical siginificant associated to nutrition (Table 5). The elderly behavior regarding to food consume that were related to liver fluke infection was analyzed and found that the majority of them had a high knowledge $(42.96 \%)$, moderately attitude $(44.44 \%)$, and moderately practice $(46.17 \%)$ (Table 6).

\section{Discussion}

Surin province is located in the northeastern Thailand where has been reported the mortality rate of liver cancer and cholangiocarcinoma in 2004 was 30.14-44.31 per 100,000 population (Sripa and Pairojkul, 2008). Cholangiocarcinoma is the bile duct cancer that related to liver fluke infection (Kaewpitoon et al., 2008a; Sripa and Pairojkul, 2008). O. viverrini infection in Surin province has been reported in 2012, and indicates that its a serious problem in the elderly group. Moreover, S. stercolaris and hookworm, was found frequently in this province (Kaewpitoon et al., 2012). Recent study found that the most of elderly had a normal nurtrition level, however, more than half of elderly age were the under-nurtition, over-nutrition and obesity. Morover, $34.04 \%$ of elderly had a waist circumference as the higher than normal level. In addition, elderly had an underlying disease mainly diabetes melletus, cardiovascular disease, hypertention, anemia. Basicly, anemia indicates the malnutritonal status of human. Previously studies have been reported that S. stercolaris and hookworm were the one caused of anemia in rural child and elderly. Anaemia was independently associated with infections including heavy hookworm infection (OR 3.45, 1.73-6.91) in a rural Ugandan population (Mugisha et al., 2013). In addition, a metaanalysis show that soil-transmitted intestinal helminth co-infection mainly S. stercolaris and hookworm, effect on anemia (Naing et al., 2013). Association of body mass index and mortality in Japanese diabetic men and women based on self-reports has been reported and found that mortality from cardiovascular disease, cancer, and renal disease showed L-shaped associations with body mass index. Compared to diabetics with body mass index of $20.0-22.9 \mathrm{~kg} / \mathrm{m}^{2}$, those with body mass index of 23.0-24.9 $\mathrm{kg} / \mathrm{m}^{2}$ and $\geq 25.0 \mathrm{~kg} / \mathrm{m}^{2}$ had lower risks of mortality from infectious disease (Kubota et al., 2015). These figures may concern for infectious disease prevention and control in Thai elderly age who had an underlying disease with diabetic myelitis, cardiovascular disease, cancer, and renal disease.

Meanwhile, diabetes melletus, cardiovascular disease, hypertension are found frequently in human who are over-weight or obesity. An android pattern of obesity is associated with a more deleterious plasma lipoprotein profile as well as hypertension and insulin resistance, resulting in an even greater increase in cardiovascular disease risk. Weight loss through caloric restriction improves the plasma lipoprotein profile (Hecker et al 1999). The most frequent risk factors to ischemic heart disease appear to be low physical activity, excess cigarette consumption, and body overweight (Geizerova et al., 1975). Food consumption of elderly was appropriated regarding vitamine, mineral, and protein, however, carbohydrate consumption was inappropriated consume and need to improve in this group. The relationship between the parameters of metabolic control and quality of carbohydrates of the diet in individuals with type 2 diabetes has been reported. The study showed that the quality of carbohydrates were strongly associated with metabolic control of type 2 diabetes (Pincheira et al., 2014). In addition, plasma glucose, insulin, and ghrelin responses were least favorable when patients with type 2 diabetes consumed a breakfast with a high glycemic index and low fiber, which suggests that reducing the glycemic index or increasing the fiber content or both of breakfasts may be a useful strategy to improve the postprandial metabolic profile of these patients (Silva et al., 2015).

Domgraphic data; gender, age group (60-70 and 71-80 years old), edutcation (elelmentary school level), and underlying diseases were significant associated to poor nutritional status in which classified by body mass 
index and weist circumference. These results are similar to previous study, the elderly' studying and nutritional behavior are the most important factors associated with poor nutrition among elderly residents of Nursing Homes in Tehran, Iran (Nazemi et al., 2015). In Taiwan, older in rural areas are need required concerned because they had significantly lower educational level, less adequate income, higher medication use, and lower self-rated healthy eating status. Moreover, rural participants had significantly lower nutritional self-efficacy, higher chance health locus of control and poorer nutritional status (Chen et al 2015). Malnutrition was significantly more frequent in elderly subjects aged more than 85 years, in females, widowed and illiterate people. Regarding health status, poor nutritional status was more common among those reporting more than three chronic diseases, taking more than three drugs daily, suffering from chronic pain and those who had worse oral health status. These results highlighted the close relationship between health status and malnutrition. The identification of potential predictive factors may allow better prevention and management of malnutrition in elderly people (Boulos et al., 2014). Socio-economic determinants of micronutrient intake and status in Europe have been reported that there is a positive association between indicators of socio-economic status and micronutrient intake and/or status (Novaković et al 2014). Meanwhile, the elderly behavior regarding to food consumed that were related to liver fluke infection was found that the majority of them had a high knowledge, moderately attitude, and moderately practice, however, many of them is found the risk factor to liver fluke infection in this group. Previous study indicates that knowledge, attitude and practice related to liver fluke infection in northeastern Thailand (Kaewpitoon et al., 2007). Rujirakul et al., (2015) has been reported that rural community people' attitude associated to liver fluke infection in Surin province. Therefore, health education pertaining good cook before consumption is need required in this risk group.

These findings data indicated that elderly age group had under-and over-nutritional status. Carbohydrate consumption was needed to improve. Meanwhile, behavior of some elderly group regarding to food consumed that related to liver fluke infection is poor, therefore, health education pertaining good nutrition is need required.

\section{Acknowledgements}

This research was supported by the national research council of Thailand, year 2012. We would like to thanks Provincial Public Health Office of Surin for their assistance.

\section{References}

Best JW (1997). Research in education. 3rd ed. eglewood cliff: prentce hall, Inc.

Bloom BS (1971). Handbook on formative and summative of student learning. New York: Mc Graw-Hill Book Company.

Boulos C, Salameh P, Barberger-Gateau P (2014). Factors associated with poor nutritional status among community dwelling Lebanese elderly subjects living in rural areas: results of the AMEL study. J Nutr Health Aging, 18, 487-94.

Chen SH, Cheng HY, Chuang YH, et al (2015). Nutritional status and its health-related factors among older adults in rural and urban areas. $J A d v$ Nurs, 71, 42-53.

Choo V (2002). WHO reassesses appropriate body-mass index for Asia Population. Lancet, 360, 235.

Esser D, Mars M, Oosterink E, Stalmach A, et al (2014). Dark chocolate consumption improves leukocyte adhesion factors and vascular function in overweight men. FASEB $J, \mathbf{2 8}$, 1464-73.

Geizerova H, Santrocek M, Hejl Z, Grafnetter D (1975). Some risk factors of ischaemic heart disease in the Prague male population. Cor Vasa, 17, 81-8.

Hecker KD, Kris-Etherton PM, Zhao G, et al (1999). Impact of body weight and weight loss on cardiovascular risk factors. Curr Atheroscler Rep, 1, 236-42.

Kaewpitoon N, Kaewpitoon SJ, Pengsaa P, et al (2007). Knowledge, attitude and practice related to liver fluke infection in northeast Thailand. World J Gastroenterol, 13, 1837-40.

Kaewpitoon N, Kaewpitoon SJ, Pengsaa P, et al (2008). Opisthorchis viverrini: the carcinogenic human liver fluke. World J Gastroenterol, 14, 666-74.

Kaewpitoon N, Kaewpitoon SJ, Pengsaa P(2008). Opisthorchiasis in Thailand: review and current status. World J Gastroenterol, 14, 2297-302.

Kaewpitoon SJ, Rujirakul R, Ueng-Arporn N, et al (2012). Community-based cross-sectional study of carcinogenic human liver fluke in elderly from Surin province, Thailand. Asian Pac J Cancer Prev, 13, 4285-8.

Kubota Y, Iso H, Tamakoshi A (2015). Association of body mass index and mortality in japanese diabetic men and women based on self-reports: the japan collaborative cohort (JACC) Study. J Epidemiol, 25, 553-8.

Lennie TA, Moser DK, Heo S, et al (2006). Factors influencing food intake in patients with heart failure: a comparison with healthy elders. J Cardiovasc Nurs, 21, 123-9.

Mahon AK, Flynn MG, Stewart LK, et al (2007). Protein intake during energy restriction: effects on body composition and markers of metabolic and cardiovascular health in postmenopausal women. J Am Coll Nutr, 26, 182-9.

McCartney DM, Byrne DG, Turner MJ (2015). Dietary contributors to hypertension in adults reviewed. Ir J Med Sci, 184, 81-90.

Mioche L, Bourdiol P, Peyron MA (2004). Influence of age on mastication: effects on eating behaviour. Nutr Res Rev, 17, 43-54.

Mugisha JO, Baisley K, Asiki G, et al (2013). Prevalence, types, risk factors and clinical correlates of anaemia in older people in a rural Ugandan population. PLoS One, 8, 78394

Naing C, Whittaker MA, Nyunt-Wai V, et al (2013). Malaria and soil-transmitted intestinal helminth co-infection and its effect on anemia: a meta-analysis. Trans $R$ Soc Trop Med Hyg, 107, 672-83.

National Statistical Office, Ministry of Information and Communication Technology, Thailand (2012). Demographic, population, and housing statistic. Key Statistics of Thailand, 6.

Nazemi L, Skoog I, Karlsson I, et al (2015). Malnutrition, prevalence and relation to some risk factors among elderly residents of nursing homes in Tehran, Iran. Iran J Public Health, 44, 218-27.

Novaković R, Cavelaars A, Geelen A, et al (2014). Socioeconomic determinants of micronutrient intake and status in Europe: a systematic review. Public Health Nutr, 17, 1031-45. 
Soraya J Kaewpitoon et al

Pincheira D, Morgado R, Alvina M, et al (2014). Quality of carbohydrates in the diet and their effect on metabolic control of type 2 diabetes]. Arch Latinoam Nutr, 64, 241-7.

Rujirakul R, Ueng-arporn N, Kaewpitoon S, et al (2015). GISbased spatial statistical analysis of risk areas for liver flukes in Surin Province of Thailand. Asian Pac J Cancer Prev, 16, 2323-6.

Silva FM, Kramer CK, Crispim D, et al (2015). A high-glycemic index, low-fiber breakfast affects the postprandial plasma glucose, insulin, and ghrelin responses of patients with type 2 diabetes in a randomized clinical trial. J Nutr, 145, 736-41

Sithithaworn P, Andrews RH, Nguyen VD, et al (2012). The current status of opisthorchiasis and clonorchiasis in the Mekong Basin. Parasitol International, 61, 10-6.

Sripa B, Pairojkul C (2008). Cholangiocarcinoma: lessons from Thailand. Curr Opin Gastroenterol, 24, 349-56.

United Nation (1999). World population prospects. The 1998 Revision, 1.

World Health Organization (1995). Physical status: the use and interpretation of Anthropometry. Technical Reports Series, Geneva, 854. 